Community Psychiatry, South Warwickshire Combined Care NHS Trust, St Michael's Hospital, St Michael's Road, Warwick CV34 5QW

\section{Community psychiatry in developing countries - Sri Lanka}

Sir: We have read the article "Community psychiatry in developing countries - a misnomer?" (Farooq \& Minks, Psychiatric Bulletin, June 2001, 25, 226-227) with interest.

The content of the article is also very relevant to our country. The majority of patients live with their families and it is in this setting that almost all psychiatrists (grossly inadequate in number for the entire population) practise. A few reasonably organised community rehabilitation centres are available only in the major cities.

We agree fully that psychiatry in developing countries should be rooted in primary health care. With this in mind, the state health authorities in Sri Lanka have taken measures to place medical officers with a basic training in psychiatry in the hospitals, where there are no qualified psychiatrists, and the medical schools too have laid a greater emphasis on giving better training in psychiatry for undergraduates.

However, adopting the term 'primary care psychiatry' would not be prudent because primary care implies a basic leve of care available to all (Declaration of Alma Ata) and would not include the greater degree of services that will have to be provided for those with psychiatric illness who live in the community. In this sense, the service provided should be more in line with the principles of community psychiatry, albeit somewhat different from that implemented in developed countries.

A. L. Kuruppuarachchi Senior Lecturer in Psychiatry, S. S. Williams Lecturer in Psychiatry, Faculty of Medicine, University of Kelaniya, Sri Lanka

\section{Lithium non-adherence}

Sir: MacCleod and Sharp's attention to lithium non-adherence is welcome (Psychiatric Bulletin, May 2001, 25, 183-186). I have concerns, however, that the authors' conclusion may instil complacency, given that they state that "all patients were defined as currently compliant".

The study uses a definition of noncompliance that requires both subjective and objective criteria to be fulfilled. A patient is then deemed 'compliant' by default if they do not meet both sets of criteria. Thus, for instance a patient in the study could have no measurable lithium in his or her serum at all but be deemed 'compliant' because he or she and his/her psychiatrist judge him or her to be so. Clinicians' judgements of patients' compliance have been found wanting in almost every study in which they have been tested. In fact the sensitivity of clinical judgement for detecting noncompliance has been quoted as an embarrassing 10\% (Stephenson et al, 1993).

The authors have not cited any of the work in this field in the past 10 years. In a recent study of compliance in lithium clinics (Schumann et al, 1999) it was noted that $53.9 \%$ of patients discontinued lithium prophylaxis at some time. Even more striking is the finding that 76 days is the median duration of continuous lithium adherence before patients elect to discontinue treatment (Johnson \& McFarland, 1996).

Given the potentially catastrophic outcomes of medicine non-adherence in major mental illness there remains a priority to identify strategies that will enhance adherence with the medicines we prescribe.

JOHNSON, R. E. \& MCFARLAND, B. H. (1996) Lithium use and discontinuation in a health maintenance organization. American Journal of Psychiatry, 153, 993-1000

SCHUMANN, C., LENZ, G., BERGHÖFER, A., et al (1999) Non-adherence with long-term prophylaxis: a 6 -year naturalistic follow-up study of affectively ill patients. Psychiatry Research, 89, 247-257.

STEPHENSON, B. J., ROWE, B. H., HAYNES, R. B., et al (1993) Is this patient taking the treatment as prescribed? Journal of the American Medica Association, 269, 2779-2781.

Ross Hamilton Consultant Psychiatrist, Block A, Clerkseat Building, Royal Cornhill Hospital, Aberdeen AB2527H.

\section{That 'Praecox feeling'}

Sir: 'Anonymous' (Psychiatric Bulletin, July 2001, 25, 275) should not be too worried that his or her children will develop schizophrenia. The Finnish adoptive family study (Tienari et al, 1994) suggests that the genetic risk is buffered by a happy family.

TIENARI, P., WYNNE, I. C., MORING, J. et al (1994) The Finnish adoptive family study of schizophrenia. Implications for family research. British Journal of Psychiatry, 164 (suppl. 23), 20-26.

Sebastian Kraemer Consultant Child and Adolescent Psychiatrist, Tavistock Clinic and Whittington Hospital, London

\section{the college}

\section{Distinction awards}

\section{College nomination procedures in England and} Wales

The Department of Health is currently undertaking a review of the procedures, operation and practice of the distinction and meritorious service award scheme. The following paper describes the College's current nomination procedure in England and Wales. It may be necessary to change this procedure when details of the new arrangements are received from the Department of Health. Further details will, therefore, appear on the College's website (http://www.rcpsych.ac.uk)
The President has identified two distinction awards advisers in each NHS region in England (apart from London, which has four advisers) and two in Wales. At least one, and often both, of the advisers will also serve on his or her regional awards committee. Statistics showing the speciality/gender/ethnic backgrounds of those consultants eligible for awards are produced each year by the College secretariat. Although awards continue to be made on merit, regions, faculties and sections are asked to consider these statistics when submitting their list of recommendations.

Towards the end of the year the distinction awards advisers in England and Wales, in consultation with the chairmen of divisions and other senior award holders, produce a list of nominations in rank order for their region. The chairmen of faculties and sections (if eligible), in consultation with senior award-holders in their faculty or section, also produce lists in rank order. Senior College officers meet to consider members who have made a significant contribution to the College. They will also consider individual nominations from College members concerned that they have been overlooked. Any College member wishing to be considered in this way should write to the College Secretary by the end of October, requesting an Advisory Committee on Distinction Awards curriculum vitae (ACDA CV) questionnaire form.

These various lists of nominations are sent to the College and are merged to 